\title{
FUTURES OPTIONS VS. CONVENTIONAL FUTURES: WHEN TO USE WHICH
}

\author{
Russ Ray \\ Department of Finance \\ University of Louisville \\ Louisville, Kentucky
}

In October of 1982, the Chicago Board of Trade introduced a remarkably innovative futures contract - options on Treasury bond futures - which offers some very impressive risk-management features not afforded by conventional futures. Unlike prior futures contracts, this particular contract was immediately successful. Indeed, the volume in this first-ever "futures option" has already exploded to over ten million contracts per year, and continues to grow. The twofold purpose of this article is to articulate these new risk-management opportunities for money managers, and to compare the hedging effectiveness of this new instrument with that afforded by conventional futures.

\section{Options are Options}

Futures options are essentially the same as any other options: calls or puts can be either bought or written (sold). As with other options, buyers of futures options post no margins; writers do. Hedging with futures options is transacted by buying - not writing - calls and puts.

\section{Call Options}

A call option on futures gives the buyer the right to assume a long position in the underlying futures contract anytime before the expiration of the option. Upon exercise of the option, the exercise (or striking) price of the option becomes the futures contract price. The risk of being adversely affected by falling interest rates can be hedged by buying call options on futures.

Consider, for example, a pension-fund manager who has just been notified that three months from now he'll receive a significant sum of money to invest for long-term purposes. The manager intends to invest the funds in U.S. Treasury bonds and he can hedge this future investment against the risk of falling interest rates in the interim by buying call options on Treasury bond futures. (See Box 1.) Assume that it's now late May, that the September 
futures price of a Treasury bond is 75-00 (yielding 12\%), and that a September/75 call option can be bought at a premium of $\$ 1,000$. Buying a September/ 75 call gives the manager the right - but not the obligation - to exercise the option and thereafter take delivery of a Treasury bond next September at a price of $\$ 75,000$ (assuming he does not close out his futures position before then).

Suppose that, by August, yields on long-term U.S. Treasury bonds do in fact drop to $10 \%$, causing the September futures price to rise from $75-00$ to $85-00$. Because exercise of the call option would result in an immediate $\$ 10,000$ gain per bond (by virtue of being able to sell a September bond at $\$ 85,000$ after having bought it at $\$ 75,000$ ), the premium on each call option will reflect at least this intrinsic value. Assuming no time value, each of the manager's September/75 calls will rise in value to $\$ 10,000$.

\section{BOX 1}

\section{HEDGING COSTS/BOND USING CALL FUTURES}

Hedge: Protect a planned, future investment against the risk of falling interest rates in the interim by buying call options on futures.

\begin{tabular}{|c|c|c|c|}
\hline & $\begin{array}{l}\text { Interest } \\
\text { Rate }\end{array}$ & $\begin{array}{l}\text { Current Price/Bond of } \\
\text { September Investment }\end{array}$ & $\begin{array}{l}\text { Hedging } \\
\text { Strategy }\end{array}$ \\
\hline lay & $12 \%$ & $\$ 75,000$ & Buy Sep/75 calls@ @ 1,000 \\
\hline ugust & $10 \%$ & $\$ 85,000$ & Sell Sep/75 calls@ @ $\$ 10,000$ \\
\hline
\end{tabular}

Consequently, when the manager lifts his hedge by selling his September/ 75 calls, the net gain of $\$ 9,000$ per bond $(\$ 10,000$ premium revenue less $\$ 1,000$ premium cost) will roughly offset the $\$ 10,000$ extra cost of each spot Treasury bond ( $\$ 85,000$ August price less $\$ 75,000$ May price) resulting from the decline in interest rates. Alternatively, the manager could have exercised his options and thereafter taken delivery of the Treasury bonds in September for $\$ 85,000$ each. Selling the options would, of course, be much easier than taking actual delivery of the Treasury bonds. Either way, the bottomline cost of the hedge per bond is the $\$ 1,000$ cost of the option. More importantly, this $\$ 1,000$ hedging cost per bond is but a small fraction of the $\$ 10,000$ extra cost the manager would have paid for each of his bonds had he not hedged. The unique advantages of a futures-option hedge over a hedge utilizing conventional futures will be enumerated following a brief discussion of put options. 


\section{Put Options}

Put options - which give buyers the right to assume a short position in the underlying futures contract - enable their holders to hedge against the risk of rising interest rates. Suppose a portfolio manager wanted to protect the value of a Treasury bond currently price at 80-00 (yielding 11\%) against the risk of rising interest rates. (See Box 2.) Suppose also that the premium on a December $/ 80$ put option were $\$ 500$. The manager could protect the value of his spot bond against the risk of rising interest rates by buying a December $/ 80$ put which gives him the right - but not the obligation - to exercise the option and thereafter sell a deliverable Treasury bond next December for $\$ 80,000$. If interest rates subsequently rose from, say, $11 \%$ to $13 \%$, causing the value of his spot bond to drop from $80-00$ to $70-00$, then his put option would be worth (at least its intrinsic value of) $\$ 1,000$. The $\$ 9,500$ increase in the value of his option would roughly offset (and, most likely, more than offset, if time value were considered) the $\$ 10,000$ decrease in the value of his spot bond. Again, the bottom-line cost of the hedge is the $\$ 500$ cost of the option.

\section{BOX 2 \\ HEDGING COSTS/BOND USING PUT FUTURES}

Hedge: Protect the value of a portfolio against the risk of rising interest rates by buying put options on futures.

\begin{tabular}{lcccc} 
& $\begin{array}{c}\text { Interest } \\
\text { Rate }\end{array}$ & $\begin{array}{c}\text { Portfolio } \\
\text { Value }\end{array}$ & \multicolumn{2}{c}{$\begin{array}{c}\text { Hedging } \\
\text { Strategy }\end{array}$} \\
Now & $11 \%$ & $\$ 80,000$ & Buy Dec/80 puts @ $\$ 500$ \\
Later & $13 \%$ & $\$ 70,000$ & Sell Dec/80 puts @ $\$ 10,000$ \\
\multicolumn{2}{c}{ Net Loss } & $=\$ 500=$ Cost of the option & & Gain $=\$ 9,500 /$ bond
\end{tabular}

\section{The Advantages of Futures Options}

The advantages of hedging with futures options instead of with conventional futures are impressive. First, the major advantage is that futures options allow hedgers to avoid potentially adverse interest rates, yet still benefit from more favorable interest rates. Such a feature is unique to this new instrument and is not afforded by conventional futures which require a hedger to forfeit more favorable interest rates.

Thus, in the first example, the manager who hedged against the risk of falling interest rates by buying a call option effectively established an interest rate floor for his future investment but not an interest rate ceiling. If interest rates had subsequently risen instead of fallen, the manager could have 
simply let his option expire worthless (assuming, again, no time value) and thereafter invested his funds at the more favorable rate. Similarly, in the second example, the manager who hedged against the risk of rising interest rates by buying a put option effectively established an interest rate ceiling but not an interest rate floor. In essence, then, futures options are insurance policies against potentially adverse interest rates, with the cost of the insurance being the cost of the option(s).

A second advantage of futures options is that margins are not required, so that the cost of hedging is generally less. If the exercise price of the option is equal to (or at least close to) the underlying futures price - as was the case in both of the examples above - then the cost of the option will generally be significantly less than the cost of margin.

Finally, a third significant advantage is that the cost of a futures-option hedge is known and fixed in advance - it is simply the cost of the option. This is not the case with conventional futures whose margins are marked to the market daily, so that hedging against incorrect expectations can cause unpredictable futures losses every day. Thus, futures options help stabilize future cash flows.

\section{The Disadvantage of Futures Options}

The disadvantage of hedging with futures options is that option costs are not refundable, whereas margins (on conventional futures) are. If interest rates remain roughly unchanged over the hedging period, then the manager hedging with futures options must incur the cost of the option regardless, whereas the manager hedging with conventional futures will have his margin refunded. Obviously, then, the question becomes - when to use which.

\section{A Volatility Criterion}

Futures options become increasingly better hedge instruments than conventional futures as interest rates become more volatile. This is so because the cost of the option is fixed, causing its hedging cost per unit of volatility to become increasingly less as volatility increases. Such is not the case with conventional futures whose margins are marked to the market. Moreover, as is likely during periods of high volatility, futures options allow the hedger to benefit from more favorable interest rates; conventional futures don't afford this feature.

On the other hand, conventional futures are better hedge instruments during periods of low volatility. This is so because, once the (unnecessary) hedge is lifted, margins are refundable, whereas option costs are not.

In general, then, the when-to-use-which decision rule is rather straightforward. For hedging periods during which low interest-rate volatility is expected, conventional futures are a better hedge; for hedging periods during which high interest-rate volatility is expected, futures options are a 
better hedge. Moreover, given that interest-rate uncertainty increases as the length of the hedging period increases, futures options are better hedge instruments for lengthy hedging periods.

The key, of course, in implementing this decision rule is to form an expectation regarding interest-rate volatility. If such expectations can be formed, then the hedging decision is rather straightforward. If interest-rate uncertainty is so great that such expectations can't be formed, then the hedging decision is made by default in favor of futures options which insure against such uncertainty. In any case, money managers are able to minimize their cost of hedging.

\section{Conclusion}

Futures options are a remarkably innovative tool with which to manage the risk of interest-rate uncertainty. By offering several risk-management features not afforded by conventional futures, they enable lenders, borrowers, and managers of money to more efficiently manage the risks associated with seemingly capricious interest rates. For money managers - especially those whose fiduciary responsibilities require them to hedge prudently futures options are a welcome element of certainty in a world which is otherwise.

\section{REFERENCES}

1. Chicago Board of Trade. Introducing Options on Treasury Bond Futures, 1982.

2. _. Opportunities in Options on Treasury Bond Futures, 1982.

3. Strategies for Buying and Writing Options on Treasury Bond Futures.

4. Ray, Russ. "Financial Futures: A Powerful Risk-Management Tool." Management Review. June, 1983.

5. . "A Policymaker's Guide to Financial Futures." Business and Public Affairs. Spring, 1983.

6. . "Financial Planning with Financial Futures." Financial Planning. November, 1985. 